\title{
PROFIL KETERAMPILAN ARGUMENTASI SISWA PADA KONSEP KOLOID YANG DIKEMBANGKAN MELALUI PEMBELAJARAN INKUIRI ARGUMENTATIF
}

\author{
Ida Farida Ch. dan Widia Fuji Gusniarti \\ Program Studi Pendidikan Kimia UIN Sunan Gunung Djati, farchemia65@gmail.com
}

\begin{abstract}
This study aims to analyze the profile argumentation skills of students of Madrasah Aliyah Negeri in Bandung which developed through inquiry argumentative learning on Colloidal Systems concept. Research instrument are assessment rubric for assess: practical work, lab report, quality of argumentation and scientific character. The data obtained through observation of eight stage of the learning process implementation: identificationi of the task and inquiry questions; collect and analyze data ; development an tentative argument, argumentation session, write an investigation report, double blind group peer review, submit and revision, and explicit and reflective discussion. Students work in groups and discussions based on the assigned task through worksheets. The results showed; Student activities shows good performance during inquiry learning argumentative implementation. The quality of students' oral argument much better than the writing. Scientific character of student-developed, especially communicative and tolerance attitude. Thus the implementation of inquiry argumentative learning on colloids can increase student activity, argumentation skills and scientific character.
\end{abstract}

Keywords: argumentative inquiry learning, argumentative skill, colloid concepts

\begin{abstract}
Abstrak
Telah dilakukan penelitian yang bertujuan untuk menganalis profil keterampilan argumentasi siswa salah satu Madrasah Aliyah Negeri di Bandung yang dikembangkan melalui pembelajaran inkuiri argumentatif pada konsep Sistem Koloid. Instrumen penelitian berupa rubrik penilaian untuk menilai: kinerja praktikum, laporan praktikum, kualitas argumentasi dan karakter ilmiah. Data-data diperoleh dari observasi pelaksanaan delapan tahap proses pembelajaran, yaitu: identifikasi tugas dan pertanyaan inkuiri; pengumpulan dan analisis data; pengembangan argumentasi tentatif, sesi argumentasi, penyusunan laporan, penilaian sejawat, revisi, dan diskusi eksplisit dan reflektif. Siswa bekerja secara kelompok dan berdiskusi berdasarkan tugas yang diberikan melalui lembar kerja. Hasil penelitian menunjukkan aktivitas siswa selama pembelajaran menunjukkan proses penerapan pembelajaran inkuiri argumentatif berjalan baik. Kualitas argumentasi siswa secara lisan jauh lebih baik dibandingkan dengan tulisan. Karakter ilmiah siswa berkembang dengan baik, khususnya sikap komunikatif dan toleransi. Dengan demikian penerapan pembelajaran inkuiri argumentatif pada konsep koloid dapat meningkatkan keaktifan siswa, mengembangkan keterampilan berargumentasi siswa, dan mengembangkan karakter ilmiah siswa.
\end{abstract}

Kata Kunci: pembelajaran inkuiri argumentatif, keterampilan argumentasi, konsep koloid

\section{PENDAHULUAN}

Dalam dekade terahir ini, pembelajaran sains semakin difokuskan untuk memberikan kesempatan agar siswa terlibat dan belajar dengan menggunakan keterampilan berpikir secara ilmiah. Konsep-konsep sains diajarkan bukan sebagai konsep 'jadi' yang harus diterima begitu saja oleh siswa, namun dibelajarkan melalui konstruksi wacana argumentatif yang merupakan esensi praktek inkuiri ilmiah (Driver et al., 2000). Berargumentasi merupakan bagian dari mengambil keputusan, mempertahankannya, dan mempengaruhi orang lain menurut data yang disertai dengan rasionalisasi (Inch et al, 2009). Keputusan tersebut bisa berupa suatu jawaban sebuah masalah atau suatu keyakinan hasil penemuan (Wojdak, 2010). Berargumentasi berarti membangun aktifitas sosiokultural melalui presentasi, interpretasi, kritik, dan revisi terhadap suatu argumen (Hakyolu, 2011). Keterampilan berargumentasi secara lisan dibutuhkan dalam pembelajaran sains khususnya untuk mengembangkan kemampuan sosiokognitif siswa. (Skuomios, 2009). Keterampilan berkomunikasi melalui lisan maupun tulisan merupakan tuntutan yang harus dimiliki seseorang untuk mengungkapkan gagasan yang dimilikinya (Arifin dkk, 2000). Dengan demikian, keterampilan berargumentasi sangat erat kaitannya dengan pembelajaran inkuiri (belajar bermakna melalui 
penemuan) yang merupakan ciri khas pembelajaran sains (Bricker \& Bell, 2008).

Salah satu konsep Kimia yang dalam pembelajarannya memiliki karakertistik pengembangan keterampilan berargumentasi adalah konsep Koloid. Merujuk pada cara analisis menurut Heron (1977), konsep koloid terdiri dari sub-sub konsep yang didominasi oleh jenis konsep abstrak dengan contoh konkrit dan konsep berdasarkan prinsip dan proses. Contoh-contoh konkrit dalam konsep koloid banyak berkaitan dengan fenomena ilmiah yang berpotensi terjadinya perbedaan pendapat dalam mengidentifikasi sifat, mengklasifikasi dan menerapkannya dalam kehidupan sehari-hari. Berbagai gagasan dan aplikasi menarik dalam kehidupan sehari-hari pada konsep koloid penting diperhatikan dalam pembelajaran Kimia. Pembelajaran Kimia yang memperhatikan aspek penting tersebut haruslah diselenggarakan dengan memperhatikan kebutuhan siswa untuk menyampaikan suatu gagasan mengenai konsep yang didapati dari temuan atau dari eksperimen yang dilakukannya.

Namun demikian, terdapat kecenderungan proses pembelajaran konsep koloid oleh guru hanya sebatas tugas baca saja dan tidak dibelajarkan secara mendalam. Hal ini sebagaimana dinyatakan Rosilawati \& Wiwit (2011), bahwa pada pembelajaran konsep koloid, siswa kurang dibimbing untuk menemukan sendiri suatu konsep Kimia, sehingga tidak memacu siswa untuk berpartisipasi aktif dalam kegiatan pembelajaran. Mereka tidak diberi kesempatan untuk belajar melalui pengalaman langsung dalam mengamati sistem, sifat-sifat dan pembuatan koloid, sehingga siswa menganggap materi pelajaran ini abstrak dan sulit dipahami. Hal yang serupa juga dinyatakan Nirmalasari (2011), bahwa penyampaian materi koloid oleh guru didominasi dengan metode ceramah dan siswa hanya mendengarkan saja.

Studi pendahuluan yang dilakukan terhadap guru Kimia pada salah satu Madrasah Aliyah Negeri di Kabupaten Bandung diketahui bahwa pembelajaran koloid sudah dianggap mencapai tujuan standar kompetensi dari segi kognitif, karena telah mencapai standar kriteria ketuntasan minimal. Namun pembelajaran tampak lebih mementingkan pengembangan aspek kognitif yang menekankan pada hafalan. Pembelajaran masih cenderung berpusat pada guru, sehingga kemampuan berpikir dan berkomunikasi siswa menjadi kurang terlatih. Meskipun guru memelajarkan konsep koloid melalui demonstrasi yang menuntut siswa untuk membuat laporan tertulis secara berkelompok, namun siswa kurang mendapatkan kesempatan untuk menemukan penjelasan dari sebuah fenomena kimia yang terjadi dan mendiskusikan hasil percobaan yang telah dilakukan dalam bentuk presentasi kelas, sehingga keterampilan argumentasi kurang berkembang.

Salah satu upaya yang dilakukan untuk memfasilitasi pengembangan keterampilan berargumentasi siswa adalah melalui pembelajaran inkuiri argumentatif. Model pembelajaran inkuiri argumentatif merupakan modifikasi dari model ADI (Argument Driven Inquiry) yang dinyatakan oleh Sampson, et al. (2010). Terdapat tiga aspek penting dalam pembelajaran yang dapat dikembangkan melalui pembelajran inkuiri argumentatif, yaitu: 1) kemampuan menggunakan penjelasan ilmiah dalam pemecahan masalah, 2) menghasilkan penjelasan ilmiah dan argumentasi, 3) berpartisipasi dalam praktek ilmiah dan diskusi (Sampson, et al., 2010).

Tahap-tahap pembelajaran Inkuiri Argumentatif yang disarikan dari Sampson (2009) sebagai berikut: 1) Identifikasi tugas dan pertanyaan inkuiri: guru memberikan tugas berupa pertanyaan inkuiri; 2) Pengumpulan dan analisis data: siswa bekerja sama untuk menyelesaikan tugas dan pertanyaan inkuri yang telah diberikan pada tahap satu dengan mengumpulkan dan menganalisis data; 3) Pengembangan argumen tentatif berupa argumen yang dibuat terdiri dari penjelasan, bukti dan penalaran menggunakan medium yang dapat disharing. Langkah ini membantu guru melihat pemikiran siswa (ide-ide, bukti dan penalaran). Pada akhirnya tahap ini memungkinkan siswa untuk mengevaluasi ide-ide bersaing dan menghilangkan penjelasan yang tidak cocok dengan data yang tersedia; 4) Sesi argumentasi, dua kelompok besar berbagi argumen dalam rangka menentukan penjelasan mana yang paling valid atau dapat diterima. Pada tahap ini siswa diberi kesempatan untuk melakukan mengumpulan data tambahan. Pengumpulan data tambahan bisa dilakukan dengan cara studi pustaka atau percobaan; 5) Penyusunan laporan investigasi berdasarkan fakta-fakta yang diperoleh dari hasil studi pustaka, sesi argumentasi dan percobaan; 6) Double blind group peer-review: penilaian laporan oleh sesama siswa berlainan kelompok ; 7) Revisi laporan personal: Masing-masing siswa memeriksa kembali laporan miliknya dan memperbaiki berdasarkan hasil peer-review tersebut; 8) Diskusi eksplisit dan reflektif dari topik untuk memberikan kesempatan siswa mengelaborasikan pengetahuan 
baru yang telah didapatkan selama pembelajran berlangsung juga untuk menghindari miskonsepsi.

Oleh karena itu, melalui penelitian dilakukan perbaikan pembelajaran pada konsep koloid dengan mengimplementasikan pembelajaran inkuiri argumentatif. Diharapkan hasil penelitian dapat memperbaiki praktek pembelajaran Kimia di Madrasah dan memberikan pengalaman belajar yang merangsang siswa untuk mengembangkan keterampilan berargumentasi dan karakter ilmiah.

\section{METODE PENELITIAN}

Melalui penelitian berbasis kelas (Hopkins, 2008) pembelajaran Inkuiri Argumentatif pada konsep koloid diimplementasikan pada siswa kelas IX dengan tujuan untuk menganalisis aktivitas dan kinerja siswa pada proses pembelajaran, pencapaian kualitas keterampilan argumentasi dan karakter ilmiah siswa. Wacana ilmiah yang dibahas adalah aplikasi koloid dalam produksi makanan, yaitu pembuatan tahu dan minyak kelapa yang menerapkan prinsip koagulasi (Esti \& Sediadi, 2000).

Untuk membantu pengumpulan data penelitian, disusun: 1) Skenario pembelajaran sebagai panduan pembelajaran; 2) Lembar kerja siswa (LKS) untuk mengembangkan pengalaman inkuiri, interaksi sosial dan keterampilan argumentasi siswa secara lisan dan tulisan; 3) Format penilaian karakter ilmiah mengukur aspek-aspek: kerjasama, keaktifan dalam menyelesaikan tugas, sikap dalam menyampaikan pendapat, dan menghargai pendapat; 4) Format penilaian kualitas argumentasi mengukur tiga aspek yaitu: kemampuan mempresentasikan argumen hasil diskusi kelompok, menjawab pertanyaan dan memberikan sanggahan; 5) Format penilaian kinerja praktikum untuk menilai aspek; merencanakan percobaan; melakukan percobaan, mengamati dan mencatat hasil, menginterpretasi hasil dan merumuskan kesimpulan; 6) Format penilaian laporan berisi kriteria penilaian laporan hasil kerja siswa untuk tahap double blind review.

Kualitas keterampilan argumentasi siswa yang diukur diklasifikasikan berdasarkan Level argumentasi Clark \& Sampson (2008), yang dimodifikasi dari kerangka kerja analisis argumentasi menurut Eduran, et al. (2005), yaitu sebagai berikut: 1) Level 0, bila argumentasi hanya claim saja; 2) Level 1, bila argumen berupa claim sederhana dengan claim berlawanan; 3) Level 2, bila argumen-argumen berupa claim disertai data, counter claim, data, jaminan atau dukungan tapi tidak mengandung sanggahan; 4) Level 3, bila argumen mengandung serangkaian claim atau counter claim disertai data, jaminan atau dukungan dengan sesekali sanggahan yang lemah; 5) Level 4, bila argumen mengandung claim disertai satu sanggahan yang dapat diidentifikasi jelas dan tepat, satu argumen dapat mengandung beberapa claim atau counter claim; 6) Level 5, bila argumentasinya luas (extended, namun tetap terkait dengan materi pembelajaran) dengan lebih dari satu sanggahan yang jelas dan tepat.

Sebelum digunakan, instrumen penelitian yang telah disusun divalidasi oleh tiga orang validator ahli menggunakan teknik Delphi untuk mereviuw konsistensi dan kevalidannya sebagai alat pengumpul data.

\section{HASIL DAN PEMBAHASAN}

\section{Aktivitas dan Kinerja siswa pada setiap tahap pembelajaran}

Proses pembelajaran dilakukan dalam tiga pertemuan tatap muka yaitu pertemuan I penerapan tahap satu, dua dan tiga, pertemuan II penerapan tahap empat dan lima, dan pertemuan III penerapan tahap enam, tujuh dan delapan. Tahapan pembelajaran inkuiri yang mengembangkan keterampilan argumentasi siswa pada konsep koloid digambarkan dalam bagan pada Gambar 1 .

Tahap 1: Guru memberikan pertanyaan untuk diselidiki: "apakah prinsip pembuatan minyak kelapa sama dengan pembuatan tahu? Agar siswa dapat menjawab permasalahan tersebut, siswa secara berkelompok dituntun untuk menjawab pertanyaan-pertanyaan inkuiri sebagaimana yang tercantum dalam LKS tersebut. Analisis kinerja siswa dalam kelompok pada tahap ini diperoleh dari penyelesaian tugas menjawab pertanyaan-pertanyaan inkuiri yang bersifat argumentatif. Terdapat lima pertanyaan yang diajukan, yaitu: 1) Pembuatan koloid; 2) Sistem koloid; 3) Jenis koloid; 4) Sifat-sifat koloid, dan; 5) Membandingkan proses pembuatan tahu dengan minyak kelapa. Berikut ini grafik hasil analisis kinerja siswa dalam menjawab pertanyaanpertanyaan inkuiri (Gambar 2). 


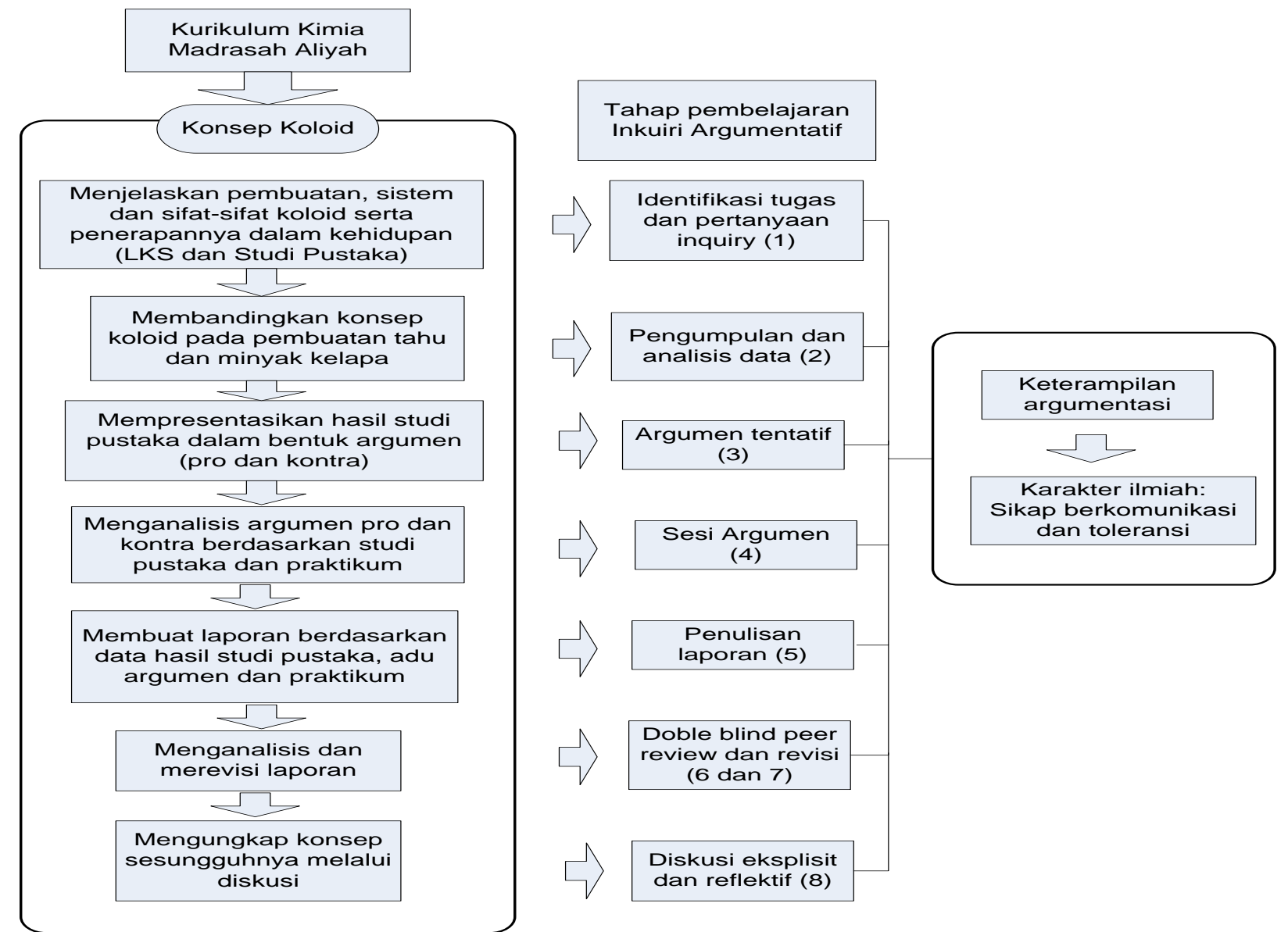

Gambar 1. Bagan Tahap-Tahap Pembelajaran Inkuiri Argumentatif pada Konsep Koloid

Berdasarkan Gambar 2, meskipun beberapa pertanyaan dapat dijawab dengan baik oleh beberapa kelompok siswa namun kinerja siswa masih kurang dalam menjawab pertanyaanpertanyaan inkuiri (rerata nilai 57). Hal ini dapat dipahami, karena pertanyaan inkuiri yang diajukan pada LKS merupakan bagian dari proses pembelajaran yang ditujukan untuk menggali pengetahuan awal dan mendorong keingintahuan siswa untuk menyelesaikan permasalahan (Sampson, 2009).

Tahap 2: Untuk memperdalam kajian dan memperbaiki jawaban yang diajukan pada tahap pertama, siswa selanjutnya mengumpulkan dan menganalisis data dengan melakukan studi pustaka dan diskusi kelompok. Siswa menggunakan berbagai judul buku pelajaran Kimia SMA kelas XI, beberapa artikel ilmiah terkait pembuatan tahu, dan siswa juga diperbolehkan mencari sumber pustaka dengan mengakses internet melalui ponsel (smart phone) yang mereka miliki mereka. Data yang diperoleh dari studi pustaka digunakan untuk menjawab pertanyaan pertanyaan yang bersifat argumentatif dalam LKS, terutama pada bagian yang mereka belum jawab dengan baik. Secara umum, keaktifan siswa bersama kelompok belajar masing-masing dengan sangat baik dalam mengumpulkan data dan fakta dari berbagai sumber dan aktif mendiskusikannya.

Tahap 3: siswa mengembangkan sebuah argumen sementara yang telah ditentukan berdasarkan tugas yang diberikan. Argumen sementara ditulis pada lembar jawaban di setiap kelompok siswa. Argumen yang dikembangkan berkaitan dengan pertanyaan utama yaitu "apakah prinsip pembuatan minyak kelapa sama dengan pembuatan tahu?". Kedelapan kelompok siswa dibagi masing-masing menjadi empat kelompok "pro" dan "kontra". Argumentasi untuk 'pro' dan 'kontra' dikembangkan terlebih dahulu secara internal dalam setiap kelompok. Setiap argument yang dikemukakan siswa pada kelompok dicatat untuk selanjutnya dipresentasikan pada tahap sesi argumen. 


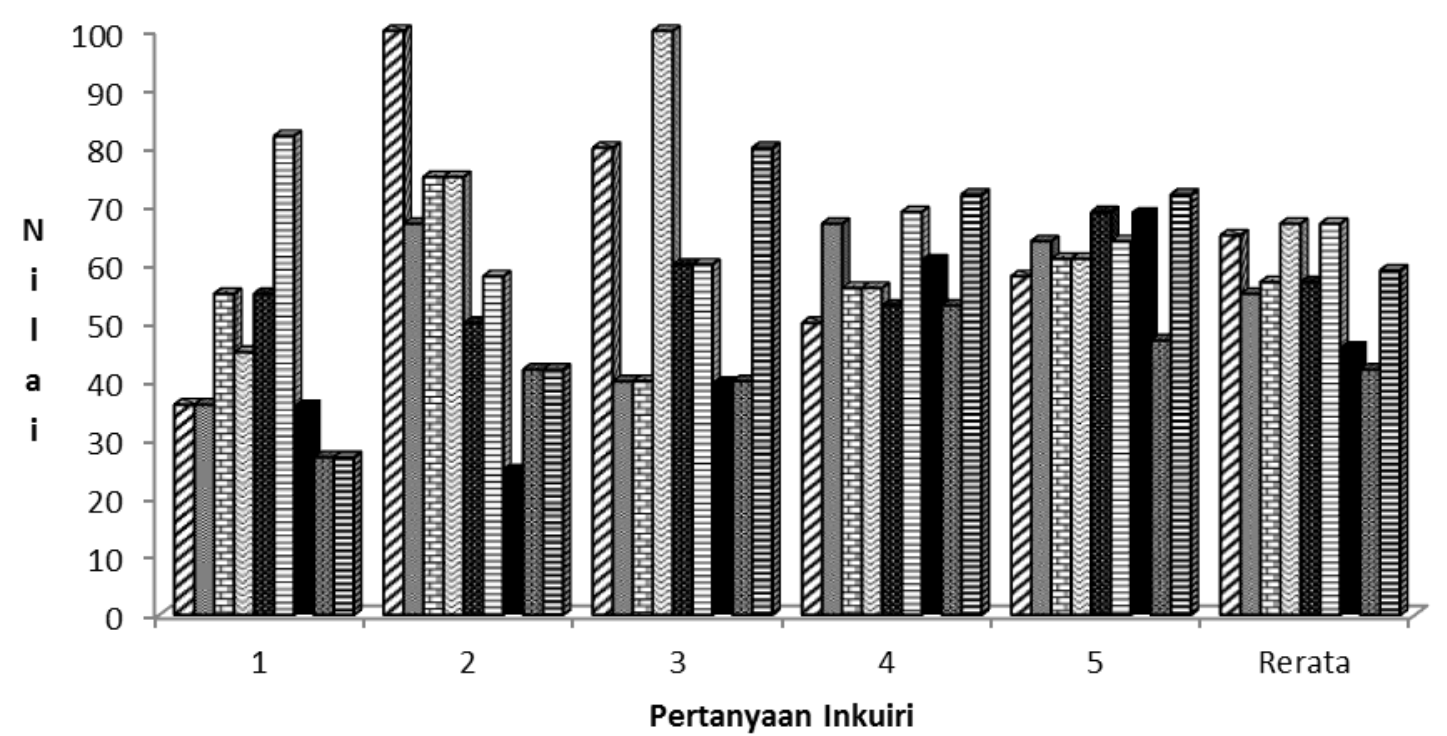

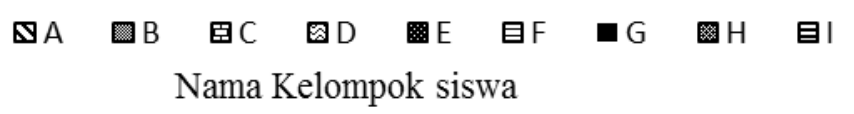

Gambar 2. Grafik Hasil Analisis Kinerja Siswa Menjawab Pertanyaan-Pertanyaan Inkuiri

Tahap 4: Perwakilan dari gabungan kelompok pro dan kontra mempresentasikan argumennya masing-masing kemudian saling menguatkan, menyanggah, mempertanyakan. Sesi argumentasi berlangsung ramai karena masing-masing kelompok terus mempertahankan argumentasi masing-masing dengan menambahkan data dan fakta tambahan dari berbagai sumber pustaka, dan sanggahan sehingga argumentasi mereka pun berkembang. Analisis kinerja siswa pada saat adu argumentasi terdiri dari tiga aspek kemampuan yang dinilai, yaitu: 1) kemampuan dalam mempresentasikan argumentasi hasil diskusi kelompok dengan jelas; 2) kemampuan menjawab pertanyaan atau memberikan sanggahan dengan tepat dan benar; 3) kemampuan menghargai pendapat, pertanyaan, atau sanggahan orang lain. Pengolahan data kinerja siswa pada sesi argumentasi berdasarkan kelompok prestasi siswa dapat dilihat pada Tabel 1.

Sesi argumentasi diakhiri dengan pencarian data tambahan melalui praktikum pembuatan minyak kelapa secara mandiri. Data tambahan ini tersebut diperlukan untuk menjawab argumentasi manakah yang benar dan menyelidiki mengapa argumennya demikian. Kinerja siswa secara individual pada pengumpulan data tambahan dinilai melalui format penilaian praktikum. Berikut ini hasil penilaian kinerja praktikum siswa yang dikelompokan ke dalam kelompok prestasi (Tabel 2).
Tabel 1. Rerata nilai kinerja Siswa pada sesi argumentasi

\begin{tabular}{cccccc}
\hline \multirow{2}{*}{ No } & $\begin{array}{c}\text { Kelompok } \\
\text { Prestasi }\end{array}$ & \multicolumn{3}{c}{ Aspek } & $\begin{array}{c}\text { Rerata } \\
\text { nilai }\end{array}$ \\
\cline { 3 - 5 } & & 1 & 2 & 3 & \\
\hline $\mathbf{1}$ & Tinggi & 82 & 96 & 100 & 93 \\
$\mathbf{2}$ & Sedang & 76 & 82 & 100 & 86 \\
$\mathbf{3}$ & Rendah & 74 & 78 & 100 & 84 \\
& Rerata nilai & 77 & 86 & 100 & 88 \\
\hline
\end{tabular}

Keterangan aspek yang dinilai:

$1=$ mempresentasikan argumentasi hasil diskusi kelompok dengan jelas

$2=$ menjawab pertanyaan atau memberikan sanggahan dengan tepat dan benar

$3=$ menghargai pendapat, pertanyaan, atau sanggahan orang lain

Tahap 5 : Setelah mendapat data tambahan yang sama dari percobaan, masing-masing siswa kemudian membuat laporan investigasi secara personal. Laporan investigasi tersebut berisi: argumen sementara yang dihasilkan dari studi pustaka lengkap dengan data dan faktanya, argumentasi berlawanan dari kelompok lain, data dan fakta tambahan yang didapat dari laporan percobaan, dan kesimpulan.

Tahap 6: Hasil kerja siswa berupa laporan dikumpulkan, kemudian guru secara acak membagikan laporan tersebut kepada siswa lain. Tujuan tahap ini agar siswa mampu menilai laporan yang dibuat temannya dan membandingkannya dengan laporan miliknya. Penilaian didasarkan pada isi laporan dan kriteria- 
kriteria yang tercantum dalam lembar peer-review. Setiap siswa diberikan kepercayaan untuk menilai laporan temannya dengan pedoman penskoran yang telah diberikan guru. Laporan masing-masing siswa ditukar dengan laporan siswa lain untuk dinilai. Pada tahap ini siswa belajar mengenai bagaimana sulitnya melakukan penilaian. Mereka juga bisa membandingkan laporan yang telah mereka buat sendiri dengan laporan temannya. Penilaian yang dilakukan, harus dianalisis secara seksama dengan pedoman penskoran agar menghasilkan nilai yang sesuai dengan isi laporan tersebut.

Tahap 7: Guru memberikan umpan balik dan menilai hasil pekerjaan siswa. Tujuannya adalah untuk mendorong siswa memperbaiki tulisan mereka berdasarkan umpan balik edukatif. Setelah guru menerima hasil peer review dari siswa, laporan yang nilainya telah sesuai dengan standar dipisahkan dari laporan yang belum sesuai standar. Siswa yang laporannya belum sesuai (sebanyak 24 orang) diharuskan merevisi laporan mereka hingga tuntas. Pemeriksaan laporan revisi tidak dilakukan secara peer-review, tetapi dilakukan oleh guru bersangkutan. Pada Gambar 3, rerata nilai laporan investigasi awal pada berbagai kelompok prestasi siswa berada dalam kategori cukup (66).

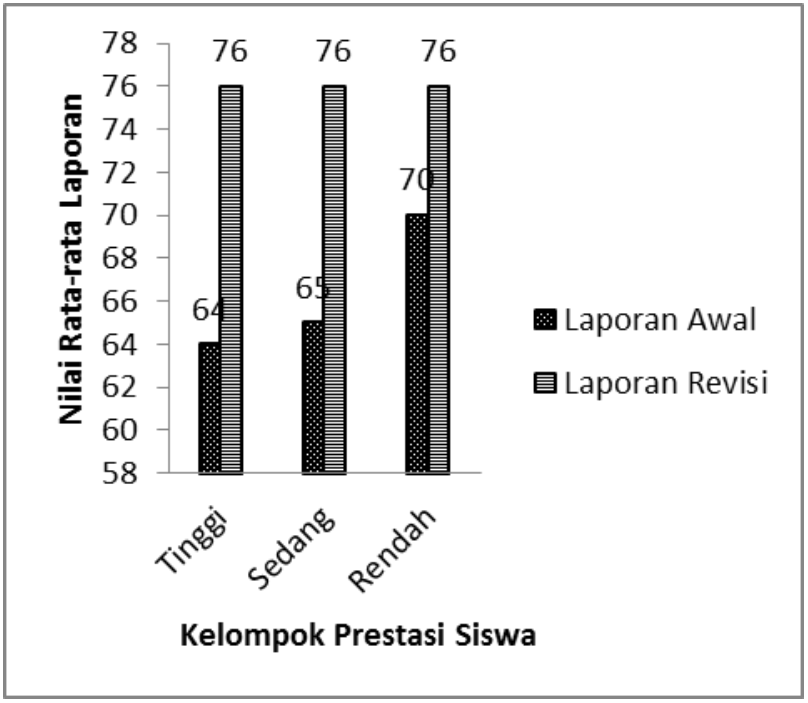

Gambar 3. Grafik rerata pencapaian nilai laporan awal dan revisi

Dilihat dari grafik pada Gambar 3 nilai ratarata tertinggi (70) pada laporan awal dicapai oleh kelompok prestasi rendah dibandingkan dengan kelompok lainnya. Hal ini, karena sebagian besar siswa kelompok rendah lebih lengkap membuat catatan data-data hasil pengamatan dibandingkan siswa kelompok lain. Kelompok tinggi lebih ringkas dalam membuat laporan sehingga banyak bagian penting yang terlewatkan.

Tabel 2. Rerata nilai kinerja praktikum setiap kelompok prestasi siswa

\begin{tabular}{lcccccccc}
\hline No & Kelompok Prestasi & \multicolumn{9}{c}{ Aspek } & Rerata Nilai \\
\cline { 3 - 7 } & & 1 & 2 & 3 & 4 & 5 & 6 & \\
$\mathbf{1}$ & Tinggi & 97 & 97 & 94 & 69 & 86 & 83 & 88 \\
$\mathbf{2}$ & Sedang & 92 & 100 & 85 & 72 & 57 & 73 & 80 \\
$\mathbf{3}$ & Rendah & 86 & 94 & 94 & 67 & 53 & 72 & 78 \\
& Rerata & 92 & 97 & 91 & 69 & 65 & 76 & 82 \\
\hline
\end{tabular}

Keterangan aspek yang dinilai:

$1=$ menjelaskan prosedur dan mengidentifikasi peralatan

$2=$ merancang percobaan

$3=$ melakukan percobaan

4= mengamati dan mencatat hasil

$5=$ menginterpretasi hasil dan merumuskan kesimpulan

$6=$ mengatur alat, menyelesaikan kegiatan, dan membersihkan alat dan tempat kerja 
Tahap 8: Pada tahap ini guru mengulang pertanyaan inkuiri yang telah dijawab siswa dengan argumentasi mereka yang bertentangan. Guru bertanya "Jadi, setelah kalian melakukan studi pustaka, sesi argumentasi, dan praktikum, apakah jawaban yang tepat mengenai konsep koloid yang digunakan dalam pembuatan tahu dan minyak kelapa?". Banyak dari siswa mengangkat tangan dan menjawab "pembuatan tahu dan minyak kelapa sama bu". Guru kembali bertanya "hal-hal apa saja yang membuatnya sama?". Siswa kemudian menjawab "sama-sama konsep koagulasi bu. Hanya saja pembuatan tahu adalah konsep koagulasi secara Kimia yaitu dengan penambahan zat lain seperti cuka, sementara pembuatan minyak kelapa konsep koagulasi secara fisika yaitu dengan pemanasan atau penambahan suhu".

\section{Kualitas keterampilan argumentasi siswa}

Penilaian kualitas argumentasi siswa didasarkan pada kategori yang dikembangkan oleh Clark \& Sampson (2008). Argumentasi yang dianalisis adalah argumentasi sementara yang dihasilkan oleh kelompok belajar pada LKS secara tulisan dan argumentasi sementara hasil diskusi kelompok "pro" dan "kontra" secara lisan. Berikut ini disajikan data persentase jumlah siswa tiap Level argumentasi yang dikemukakan secara tulisan (Tabel 3).

Tabel 3. Kualitas keterampilan argumentasi tulisan berdasarkan \% jumlah siswa tiap kelompok

\begin{tabular}{cccccccc}
\multicolumn{10}{c}{ prestasi } \\
\hline No & $\begin{array}{c}\text { Kelompok } \\
\text { Prestasi }\end{array}$ & \multicolumn{7}{c}{$\begin{array}{c}\text { \% Jumlah siswa tiap Level } \\
\text { argumentasi tulisan }\end{array}$} \\
\cline { 3 - 8 } & & 0 & 1 & 2 & 3 & 4 & 5 \\
$\mathbf{1}$ & Tinggi & - & 9 & 15 & 3 & - & - \\
$\mathbf{2}$ & Sedang & - & 8 & 24 & 3 & - & - \\
3 & Rendah & - & 6 & 18 & 3 & - & - \\
& Jumlah & - & 33 & 58 & 3 & - & - \\
\hline
\end{tabular}

Pada tahap membuat argumen sementara, argumentasi yang dihasilkan secara tulisan menyebar dari kualitas argument level satu hingga level tiga, namun lebih dari separuhnya $(58 \%$ siswa) dominan pada kualitas level 2. Argumentasi level 2 adalah argumentasi yang terdiri dari Claim, disertai data, tetapi tidak memiliki sanggahan. Contoh argumentasi level 2 pada siswa Claim "prinsip pembuatan tahu sama dengan pembuatan minyak kelapa karena sama-sama mengalami koagulasi”. Berikut disajikan data persentasi jumlah siswa tiap level argumentasi yang dikemukakan secara tulisan (Tabel 4).
Tabel 4. Kualitas keterampilan argumentasi lisan berdasarkan \% jumlah siswa tiap kelompok prestasi

\begin{tabular}{cccccccc}
\hline \multirow{2}{*}{ No } & $\begin{array}{c}\text { Kelompok } \\
\text { Prestasi }\end{array}$ & \multicolumn{5}{c}{$\begin{array}{c}\text { \% Jumlah siswa tiap Level } \\
\text { argumentasi lisan }\end{array}$} \\
\cline { 3 - 8 } & & $\mathbf{0}$ & $\mathbf{1}$ & $\mathbf{2}$ & $\mathbf{3}$ & $\mathbf{4}$ & $\mathbf{5}$ \\
\hline $\mathbf{1}$ & Tinggi & - & - & 15 & - & - & $\mathbf{1 5}$ \\
$\mathbf{2}$ & Sedang & - & - & 24 & - & - & $\mathbf{2 7}$ \\
$\mathbf{3}$ & Rendah & - & - & 18 & - & - & $\mathbf{1 2}$ \\
& Jumlah & - & - & $\mathbf{4 5}$ & & - & $\mathbf{5 5}$ \\
\hline
\end{tabular}

Pada saat sesi argumentasi, kualitas argumentasi yang dihasilkan secara lisan yang dominan adalah level dua dan level lima. Argumentasi level lima adalah argumentasi yang terdiri dari claim, argumen-argumen yang luas dengan lebih dari satu sanggahan yang mengikutinya disertai data, tetapi tidak memiliki sanggahan. Contoh argumentasi level 5 pada siswa Claim "prinsip pembuatan minyak kelapa tidak sama dengan prinsip pembuatan tahu karena emulsi santan kurang stabil dibanding emulsi susu kedelai, pembuatan tahu mengalami penambahan zat lain, minyak tidak, dan pembuatan tahu tidak menghilangkan air".

Pada penelitian ini ditemukan fakta bahwa kualitas prestasi siswa yang termasuk tinggi tidak begitu mempengaruhi kualitas argumen sementara yang mereka kembangkan dari studi pustaka. Hal tersebut sesuai dengan hasil penelitian Hakyolu \& Bekiroglu (2011), yang menyatakan bahwa tidak ada hubungan antara tingkat prestasi siswa dengan keterlibatan mereka menggunakan argumentasi.

Wodjack (2010) menyatakan, bahwa argumen yang valid hanya bisa diperoleh dari hasil analisis kritis dan membuat suatu argumentasi ilmiah dimulai dari membuat argumen logis. Pernyataan tersebut menggambarkan betapa sulitnya membuat suatu argumen terlebih jika siswa kurang begitu terlatih memanfaatkan sumber pustaka. Pada penelitian ini siswa mengalami kesulitan dalam membuat argumen sementara, karena kurangnya efesiennya waktu dan cara mereka memanfaatkan pustaka yang relevan melalui sumber-sumber. Mereka juga belum terbiasa membuat suatu argumen, karena pembelajaran sebelumnya kurang memberikan kesempatan bagi mereka untuk mengemukakan pendapat. Belajar membuat argumen yang baik tidak bisa dilakukan dalam waktu singkat. Sebagaimana yang diungkapkan oleh Walker 
(2010), bahwa belajar berargumentasi perlu dilakukan pada periode yang cukup lama.

Dalam pembelajaran tahap akhir, teramati bahwa siswa lebih aktif dalam berpendapat (77\%) dibanding bertanya (64\%). Hal ini membuktikan bahwa keterampilan siswa dalam berargumentasi atau menyatakan pendapat telah meningkat seiring dengan proses pembelajaran.

\section{Pengembangan Karakter Ilmiah Siswa}

Secara umum, karakter ilmiah yang dikembangkan secara tidak langsung dalam pembelajaran terdiri dari sikap disiplin, jujur, tertib, tanggung jawab, toleransi, teliti, peduli lingkungan, komunikatif, gemar membaca, kerja keras, dan mandiri. Tetapi karakter ilmiah siswa yang secara sengaja dikembangkan dalam adalah sikap komunikatif dan toleransi. Data sikap komunikatif dan toleransi yang dikembangkan diperoleh melalui observasi ketika siswa mengerjakan LKS bersama kelompok belajarnya. Penilaian pengembangan karakter ilmiah siswa pada pembelajaran terdiri dari empat aspek, yaitu: 1) kerjasama dalam kelompok; 2) keaktifan dalam menyelesaikan tugas; 3) keaktifan dalam menyampaikan pendapat; 4) menghargai pendapat sesama anggota kelompok. Hasil penilaian ini kemudian dikelompokkan ke dalam kelompok prestasi karena dinilai secara individu sebagaimana tertuang dalam Tabel 5.

Tabel 5. Rerata Nilai Karakter Ilmiah Siswa pada Pembelajaran

\begin{tabular}{ccccccc}
\hline & \multirow{2}{*}{ No } & $\begin{array}{c}\text { Kelompok } \\
\text { Prestasi }\end{array}$ & \multicolumn{5}{c}{ Aspek } & \multirow{2}{*}{ Rerata } \\
\cline { 3 - 6 } & Tinggi & 74 & 85 & 85 & 89 & 83 \\
\hline $\mathbf{1}$ & Sedang & 76 & 73 & 80 & 82 & 77 \\
$\mathbf{2}$ & Rendah & 70 & 67 & 67 & 78 & 70 \\
$\mathbf{3}$ & Rata-rata & 73 & 75 & 77 & 83 & 77 \\
\hline
\end{tabular}

Keterangan aspek yang dinilai:

$1=$ Kerjasama dalam kelompok

$2=$ Keaktivan dalam menyelesaikan tugas

$3=$ Keaktivan dalam menyampaikan pendapat

4= Menghargai pendapat sesama kelompok

Berdasarkan Tabel 5, secara keseluruhan, rerata karakter ilmiah siswa pada pembelajaran termasuk baik. Hal ini ditunjukkan dengan nilai rata-rata secara keseluruhan adalah 77 .

\section{PENUTUP}

\section{Simpulan}

Berdasarkan hasil penelitian dan analisis data dapat disimpulkan bahwa aktivitas siswa selama penerapan pembelajaran Inkuiri Argumentatif untuk mengembangkan keterampilan berargumentasi siswa pada konsep koloid dapat dikategorikan berjalan dengan baik. Kinerja siswa pada setiap tahapan pembelajaran Inkuiri Argumentatif memperlihatkan hasil yang baik. Kualitas argumentasi siswa secara tertulis yang teridentifikasi tersebar dari kualitas satu hingga level tiga dan dominan pada level dua. Pada argumentasi secara lisan pencapaiannya sebanding yaitu pada Level dua dan lima. Karakter ilmiah siswa yang dikembangkan secara sengaja dalam pembelajaran adalah sikap komunikatif dan toleransi. Secara keseluruhan, rerata karakter ilmiah siswa pada pembelajaran termasuk baik.

\section{Saran}

Berdasarkan hasil penelitian yang telah dilakukan oleh penulis, maka saran yang dapat dikemukakan sebagai berikut: Untuk memulai semua tahap guru hendaknya memberikan penjelasan mengenai langkah-langkah yang akan dilakukan siswa dalam pelajaran disertai dengan alokasi waktu yang diberikan. Pada sesi argumentasi guru harus memberikan rangsangan kepada masing-masing kelompok siswa untuk mempertahankan argumentasinya masing-masing sehingga suasana debat menjadi optimal. Pembelajaran dengan menggunakan model ini juga hendaknya tidak hanya diterapkan pada materi koloid saja, namun dapat diterapkan pada materi Kimia yang lain.

\section{DAFTAR PUSTAKA}

Berland, Brian J. 2008. Making Sense of Argumentation and Explanation. Science Education 93:26-55. (www.interscience.wile y.com).

Bricker LA, Bell P. 2008. Conceptual of argumentation from science studies and the learning sciences and their implication for practices of science education. Science Education 92(3):473-498.

Driver R, Newton P, Osborne J. 2000. Establishing the norms of scientific argumentation in classrooms. Science Education 84: 287-312.

Erduran SJ, Osborne S. Simon. 2005. The Role of Argumentation in Developing Scientific Literacy. Research and The Quality of Science Education (Ed. Boersma, et al). Dordrecht: Springer.

Esti AS. 2000. Pengawetan dan Bahan Kimia.(Online).http://www.ristek. go.id. [25 Maret 2008]. 
Hakyolu H, Bekiroglu FO. 2011. Assessment of Student's Science Knowledge Levels and Their Involvement with Argumentation. International Journal of Cross-Disciplinary Subjects in Education (IJCDSE) 2(1):264269.

Hopkins D. 2008. A teacher's guide to classroom research (Fourth Ed). New York : Mc Graw Hill.

Inch ES, Warnick B, Endres D. 2006. Critical Thinking and Commnication: The Use of Reason in Argument (Fifth Ed). Boston: Pearson Education

Nirmalasari M. 2011. Pengembangan Model Memorization Learning dalam Meningkatkan Pemahaman Peserta Didik pada Pelajaran Kimia SMA. Wahana Fisika 2:178-190

Rosilawati I, Wiwit. 2011. Penerapan Pembelajaran Kooperatif tipe STAD dengan peta konsep untuk meningkatkan hasil belajar dan ketuntasa belajar siswa pada Konsep koloid. Prosiding Seminar Nasional Pendidikan MIPA. PMIPA FKIP Universitas Lampung.
Sampson V. 2009. The impact of Argument-Driven Inquiry on three scientific practices. Paper presented at the Annual International Conference of the National Association of Research in Science Teaching (NARST). Garden Grove, CA.

Sampson V, Walker J, Dial K, Swanson J. 2010. "Learning to write in undergraduate chemistry: The impact of Argument-Driven Inquiry." Paper presented at the 2010 Annual International Conference of the National Association of Research in Science Teaching (NARST). Philadelphia, PA.

Skoumios M. 2009. The Effect of Sociocognitive Conflict on Student's Dialogic Argumentation about Floating dan Sinking. International Journal of Environmental \& Science Education (IJESE) 4(4):381-399.

Wojdak JM. 2010. An Attention-Grabbing Approach to Introducing Students to Argumentation In Science. Bioscience education 15. 
Keterampilan Argumentasi Siswa Pada Konsep Koloid 